\title{
Determination of Different Trace Heavy Metals in Children's Plastic Toys Imported to the West Bank/Palestine by ICP/MS-Environmental and Health Aspects
}

\author{
Mutaz Al-Qutob ${ }^{1,2^{*}}$, Ahmad Asafra2 ${ }^{2}$, Tharwat Nashashibi2 ${ }^{2}$ Ahmad A. Qutob ${ }^{3}$ \\ ${ }^{1}$ Department of Earth and Environmental Studies, Faculty of Science and Technology, Al-Quds University, \\ Jerusalem \\ ${ }^{2}$ Aquatic and Aquaculture Research Laboratory, Al-Quds University, Jerusalem \\ ${ }^{3}$ Department of Electronic Engineering, Faculty of Engineering, Al-Quds University, Jerusalem \\ Email: "qutob@planet.edu
}

Received 14 July 2014; revised 12 August 2014; accepted 28 August 2014

Copyright (C) 2014 by authors and Scientific Research Publishing Inc.

This work is licensed under the Creative Commons Attribution International License (CC BY).

http://creativecommons.org/licenses/by/4.0/

(c) (i)

\section{Abstract}

The main aim of this study is to assess the quality of inexpensive plastic toys imported to Palestinian Markets. The content of heavy metals ( $\mathrm{Pb}, \mathrm{Cd}, \mathrm{Cr}, \mathrm{Hg}$, $\mathrm{As}, \mathrm{Se}, \mathrm{Ba}$, and $\mathrm{Zn}$ ) was analyzed in $\mathbf{5 0}$ plastic toys purchased from local markets in Palestine and 17 plastic toys purchased from Israeli markets for comparison. After the digestion of samples with concentrated nitric acids and hydrogen peroxide using a microwave digester, the concentrations of the selected heavy metals were determined by ICP-MS Agilent 7500 in Al-Quds University. Results revealed that $40 \%$ of the Palestinian toy samples had high concentration (above international limits) of $\mathrm{Pb}, 30 \% \mathrm{of} \mathrm{Cd}, 34 \% \mathrm{of} C r$, $6 \%$ of $\mathrm{Hg}, 42 \%$ of As, $32 \%$ of Se, $20 \%$ of Ba, and $40 \%$ of $\mathrm{Zn}$. On the other hand, $95 \%$ of the Israeli samples were safe, and their concentrations were less than the maximum internationally allowable limits. In the same context, ten toy samples ( $2.5 \mathrm{gm}$ each) had been crushed and dipped for 8 hours in a solution of artificial saliva. The solution was acidified and tested for heavy metal concentrations, but none of the migration concentrations exceeded the international maximum allowable limit. High levels of heavy metal concentrations, found in the plastic toys from the Palestinian markets could form a health hazard to children and put their lives at risk. It could be also an indirect source for environmental pollution.

"Corresponding author.

How to cite this paper: Al-Qutob, M., Asafra, A., Nashashibi, T. and Qutob, A.A. (2014) Determination of Different Trace Heavy Metals in Children's Plastic Toys Imported to the West Bank/Palestine by ICP/MS-Environmental and Health Aspects. Journal of Environmental Protection, 5, 1104-1110. http://dx.doi.org/10.4236/jep.2014.512108 


\section{Keywords}

\section{Plastic Toys, Heavy Metals Content, Palestinian Markets, Israeli Markets}

\section{Introduction}

Children exposure to heavy metals in contaminated plastic toys continues to be a major health concern. Heavy metals including lead $(\mathrm{Pb})$, cadmium (Cd), arsenic (As), chromium (Cr), selenium (Se), mercury (Hg), barium $(\mathrm{Ba})$, and zinc $(\mathrm{Zn})$ are usually added to a wide variety of plastic toys, in order to provide the necessary stability, and to impart some characteristics such as softness, brightness, and flexibility to those products. There is a concern that these metals can migrate from soft toys when they are chewed and sucked by children and thus pose toxic effects in the long term. Heavy metals will also be released from the plastic to the Environment at the end of the Plastic lifecycle.

In the Environment metals have been linked to chronic diseases that are on the rise, including breast cancer, learning and developmental disabilities, and reproductive health problems [1]. Therefore, analysis of such elements and preventive action is important to ensure toy safety. The popular outcry against plastic toys swept most of the developed countries of the world and some of them took practical steps such as the United States, which has recalled an estimated 20 million Chinese-made toys by Mattel on August 14, 2007 [2] [3]. Toy safety is a joint responsibility among governments, manufacturers, regulatory bodies and parents. The responsibility is multiplied in areas that have difficult economic and harsh occupying circumstances such as the Palestinian case. Goods often enter Palestinian Territories without restrictions, controls, standards, or needs; especially plastic toys [4]. The Palestinian Authority has no authority over ports and has no authority over border crossings. The Israeli side is the one who does all these tasks and monitor the movement of goods coming from overseas and examine their brands and their conformity with international standards. The problem lies in that there is no official Palestinian presence in Israeli ports therefore the handle occurs directly between the Palestinian merchant and the port authority and no one can be sure that Palestinian goods have been examined or not. Thus, there is a quantity of toys entering the Palestinian Authority which does not meet international standards.

It has already been reported that these deadly products had reached markets of very advanced countries such as the United States [2] [3]. These developed countries have technology, resources, and a system of laws, legislation, and strict control. Is it conceivable that Palestinian markets are fortified against them?! We firmly believe not. If we remain silent on this matter, the problem will become more complicated, and the generation of babies will be born pre-polluted with potentially harmful levels of heavy metals that may possibly cause lifelong health and environmental problems. Accordingly, our main objective in this study was to assess and measure the concentrations of eight heavy metals ( $\mathrm{Pb}, \mathrm{Cd}, \mathrm{Hg}, \mathrm{As}, \mathrm{Cr}, \mathrm{Se}, \mathrm{Ba}$, and $\mathrm{Zn}$ ) in plastic toys imported to Palestine and to raise awareness to policy makers on the need of urgent national policy for the removal of heavy metals from children toys in the Palestinian territories.

\section{Experimental}

\subsection{Sampling}

Headings, fifty popular cheap priced plastic toys were purchased from three major Palestinian cities (Hebron, Nablus and Ramallah) and 17 plastic toys were purchased from the Israeli markets (west Jerusalem, Beit Safafa neighborhood). They were randomly selected from shops selling toys whole sale, retail, and stalls considering accessibility to children from middle and low-income. The toys were typically bright in color, available in largely darker shades of red, yellow, purple, blue, and green or a mix of these colors. Some were soft and easily squeezable while others were not flexible enough. Each toy was weighed, and given a special description in terms of color and shape. All toys were further grinded, crushed and sieved through $<2 \mathrm{~mm}$ nylon sieve, mixed as necessary to homogenize the samples and were stored in closed cans.

\section{Digestion and ICPMS Analysis}

Toy samples were digested using Microwave Assisted Acid Digestion of Siliceous and Organically Based Matrices (MARS 6, Analytk Jena Company) according to the method described by [5] Kingston and Haswell, 1997. 
The samples were then analyzed for heavy metal ( $\mathrm{Pb}, \mathrm{Cd}, \mathrm{Cr}, \mathrm{Hg}$, As, Se, Ba, and $\mathrm{Zn}$ ) contents by ICP/MS (Agilent technologies 7500 series) at the aquatic environmental laboratory in Al-Quds University. Each sample was analyzed three times and the results are expressed as mean \pm SD (SD: standard deviation). The operating conditions are as follows: nebulizer gas (argon) flow rate: $0.9 \mathrm{~L} / \mathrm{min}$, auxiliary gas (argon) flow $0.3 \mathrm{~L} / \mathrm{min}$, plasma (argon) gas flow: $15 \mathrm{~L} / \mathrm{min}$, reaction gas flow (helium) $4 \mathrm{~mL} / \mathrm{min}$, lens voltage $7.25 \mathrm{~V}$, ICP RF power: $1100 \mathrm{~W}, \mathrm{CeO} / \mathrm{Ce}=1 \%$, and $\mathrm{Ce}^{2+} \mathrm{Ce}^{1+}=1 \%$. For accurate quantitative determination an internal standard method was used using (In) as internal standard and a multi-standard calibration method: (22 metals standard (Ag 10 $\mathrm{mg} \cdot \mathrm{L}^{-1}$, Al $50 \mathrm{mg} \cdot \mathrm{L}^{-1}$, B $50 \mathrm{mg} \cdot \mathrm{L}^{-1}$, Ba $10 \mathrm{mg} \cdot \mathrm{L}^{-1}$, Bi $100 \mathrm{mg} \cdot \mathrm{L}^{-1}$, Ca $10 \mathrm{mg} \cdot \mathrm{L}^{-1} \mathrm{Cd} 10 \mathrm{mg} \cdot \mathrm{L}^{-1}$, Co $10 \mathrm{mg} \cdot \mathrm{L}^{-1}$, Cr $50 \mathrm{mg} \cdot \mathrm{L}^{-1}$, Cu $10 \mathrm{mg} \cdot \mathrm{L}^{-1}$, Fe $10 \mathrm{mg} \cdot \mathrm{L}^{-1}$, K $100 \mathrm{mg} \cdot \mathrm{L}^{-1}$, Li $50 \mathrm{mg} \cdot \mathrm{L}^{-1}$, Mg $10 \mathrm{mg} \cdot \mathrm{L}^{-1}$, Mn $10 \mathrm{mg} \cdot \mathrm{L}^{-1}$, Mo 50 $\mathrm{mg} \cdot \mathrm{L}^{-1}$, Na $50 \mathrm{mg} \cdot \mathrm{L}^{-1}$, Ni $50 \mathrm{mg} \cdot \mathrm{L}^{-1}$, Pb $100 \mathrm{mg} \cdot \mathrm{L}^{-1}$, Sr $10 \mathrm{mg} \cdot \mathrm{L}^{-1}$, Tl $50 \mathrm{mg} \cdot \mathrm{L}^{-1}$, Zn $10 \mathrm{mg} \cdot \mathrm{L}^{-1}$, matrix $5 \%$ $\mathrm{HNO}_{3}$ ). Calibration curves for all metals analyzed were constructed by plotting the ratio of the intensity of the analyte metal to that of the internal standard (In) vs. concentration of the trace metal in ppb and results showed that the calibration curves are linear with correlation coefficient $\left(\mathrm{r}^{2}\right)$ greater than 0.999 for the trace metals.

\section{Results and Discussion}

\subsection{Heavy Metal Concentrations in Toys Purchased from Palestinian Market}

Lead $(\mathrm{Pb})$ concentration ranged from 0.76 to $6036 \mathrm{mg} \cdot \mathrm{L}^{-1}$ with an average of $611.96 \mathrm{mg} \cdot \mathrm{L}^{-1}$. Forty percent of the toy samples (twenty out of fifty toys samples), contained $\mathrm{Pb}$ with concentration higher than $90 \mathrm{mg} \cdot \mathrm{L}^{-1}$, which is much more than the maximum allowable value according to international standards [6] (ISO 8124-3, 2010) (Table 1). There was a close correlation between the color of the sample and the concentration of $\mathrm{Pb}$. Most of the yellow samples contained the highest concentration of $\mathrm{Pb}$ attributed mainly to lead (II) chromate $\left(\mathrm{PbCrO}_{4}\right.$, "chrome yellow") used to produce pigments [7]. Basic lead salts are commonly used as thermal stabilizers to enhance material properties and to reduce material costs (fillers) in Plastics [8] [9].

Mercury ( $\mathrm{Hg}$ ) concentration ranged from 0.12 to $85.9 \mathrm{mg} \cdot \mathrm{L}^{-1}$ with an average of $18.94 \mathrm{mg} \cdot \mathrm{L}^{-1}$ (Table 1, Figure 1). $\mathrm{Pb}$ and $\mathrm{Hg}$ are linked with neurodevelopment problems and possible autistic disorders in children [10] [11]. Six percent of the samples contained Hg concentration above the allowable value (Table 1). Most manufacturers of PVC around the world use natural gas or petroleum as the feedstock or raw material from which the plastic is manufactured. However, most plastic manufacturing in China uses a different process that starts with coal as the feedstock. In that coal-based process, mercury is used as a catalyst to spark the chemical reaction among ingredients. Some of the mercury catalyst is lost during this industrial process and must be continually replenished. It is poorly understood exactly where the lost mercury ends up and how it gets there, but surely part of it is mixed in processed material [12].

Chromium (Cr) concentrations varied from 6.76 to $2468.5 \mathrm{mg} \cdot \mathrm{L}^{-1}$ with an average of $204.22 \mathrm{mg} \cdot \mathrm{L}^{-1}$ (Table 1 ). $34 \%$ of the samples contained $\mathrm{Cr}$ concentration more than $60 \mathrm{mg} \cdot \mathrm{L}^{-1}$ which is above the allowable value (ISO 8124-3, 2010). Chromium is widely used as a valuable dye and as a coloring for PVC material, as well as heat stabilizer. Samples with high lead concentrations also often contained chromium. This could be attributed to that

Table 1. Concentration of eight heavy metals $\left(\mathrm{mg} \cdot \mathrm{L}^{-1}\right)$ in toys from Palestinian markets. Results expressed as (minimum, maximum, average, standard deviation (SD), and relative standard deviation (RSD)), as well as their ISO 8124-3 limits and total samples exceeding limits.

\begin{tabular}{|c|c|c|c|c|c|c|c|c|}
\hline Heavy Metal & $\mathrm{Pb}$ & $\mathrm{Cd}$ & $\mathrm{Cr}$ & $\mathrm{Hg}$ & As & Se & $\mathrm{Ba}$ & $\mathrm{Zn}$ \\
\hline $\operatorname{Minimum}\left(\mathrm{mg} \cdot \mathrm{L}^{-1}\right)$ & 0.76 & 0.47 & 6.76 & 0.12 & 2.91 & 16.06 & 4.42 & 9.20 \\
\hline Maximum $\left(\mathrm{mg} \cdot \mathrm{L}^{-1}\right)$ & 6036.0 & 436.42 & 2468.5 & 85.9 & 2486.5 & 2833.1 & 16074.4 & 10725.0 \\
\hline Average $\left(\mathrm{mg} \cdot \mathrm{L}^{-1}\right)$ & 611.96 & 92.20 & 204.22 & 18.94 & 180.03 & 453.97 & 1291.81 & 1454.8 \\
\hline $\mathrm{SD}$ & 3.07 & 4.19 & 5.03 & 5.73 & 6.01 & 2.99 & 7.99 & 7.45 \\
\hline RSD (\%) & 0.5 & 4.5 & 2.4 & 30 & 3.3 & 0.65 & 0.61 & 0.5 \\
\hline ISO $8124-3$ limits & 90 & 75 & 60 & 60 & 25 & 500 & 1000 & - \\
\hline$\%$ of total samples exceeding limits & 40 & 30 & 34 & 6 & 42 & 32 & 20 & ${ }^{*} 40$ \\
\hline
\end{tabular}




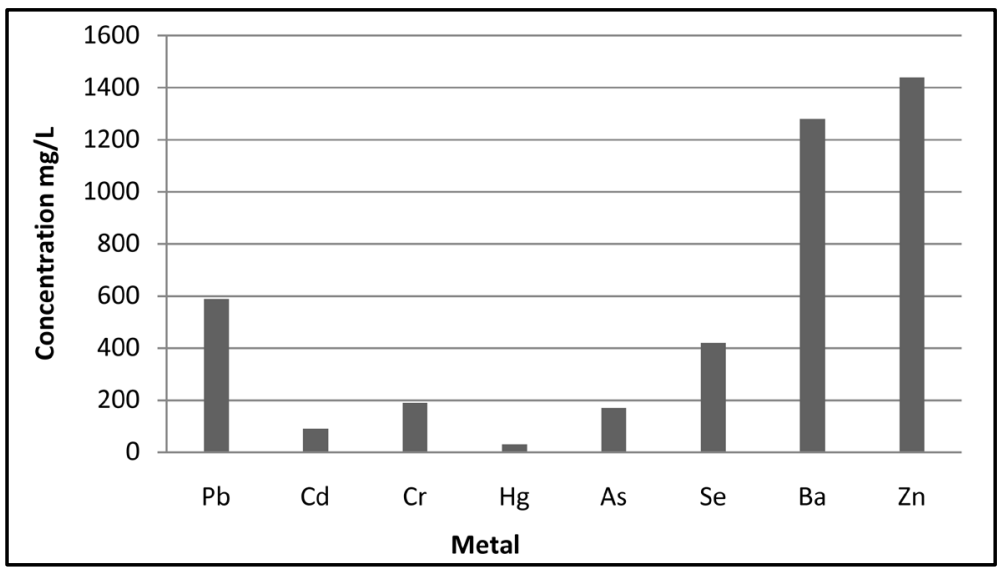

Figure 1. Average of heavy metals total content in Palestinian toy samples.

both elements were used as dyes or pigments rather than stabilizers and the compound combining them was lead chromate.

Cadmium $(\mathrm{Cd})$ concentrations were ranging from 0.47 to $436.42 \mathrm{mg} \cdot \mathrm{L}^{-1}$ with an average of $92.2 \mathrm{mg} \cdot \mathrm{L}^{-1}$. $30 \%$ of the samples contained cadmium concentration above the maximum allowable value $\left(75 \mathrm{mg} \cdot \mathrm{L}^{-1}\right)$. High cadmium concentrations were noted in deep orange toy samples. Cadmium is used as a thermal stabilizer for polyvinyl chloride (PVC) plastic during the manufacturing process. It replaces labile chlorine atoms in the polymer and modifies chain reactions. It inhibits the elimination of hydrogen chloride and interrupts the formation of polyene sequences in the polymer which is attributed to its formation of the gradual demise of yellow and its conversion to orange and then red and brown [13].

Barium (Ba) concentrations ranged from 4.42 to $16074.4 \mathrm{mg} \cdot \mathrm{L}^{-1}$ with an average of $1291.81 \mathrm{mg} \cdot \mathrm{L}^{-1} .20 \%$ of the samples had high barium concentrations above the allowable value of $1000 \mathrm{mg} \cdot \mathrm{L}^{-1}$. Usually its compounds like barium sulfate, barium oxide and barium sulfide form the source of white and yellow light in toys' materials.

Zinc (Zn) and selenium (Se) concentrations ranged from 9.2 to $10,725.0 \mathrm{mg} \cdot \mathrm{L}^{-1}$ with an average of 1454.8 $\mathrm{mg} \cdot \mathrm{L}^{-1}$ and from 16.06 to $2833.0 \mathrm{mg} \cdot \mathrm{L}^{-1}$ with an average of $453.97 \mathrm{mg} \cdot \mathrm{L}^{-1}$ respectively. $\mathrm{Zn}$ average was far lower than the migration limit set by the EU Directives of $46,000 \mathrm{mg} \cdot \mathrm{L}^{-1}$ in scraped-off material [14] (EU Directives, 2009), but in $40 \%$ of samples Zn concentration was $>1000 \mathrm{mg} \cdot \mathrm{L}^{-1}$. Zinc could be used in toys in the form of zinc borate or zinc omadine (zinc 2-pyridinethiol-1-oxide). Zinc borate is used alone or in combination with other halogen synergists, such as antimony trioxide as a fire retardant additive for PVC products and as an anticorrosive pigment in coatings [15] (Erdodu, 2004). Zinc omadine is used as antimicrobial agent in PVC plastics [16]. Due to its low solubility in water $\left(8 \mathrm{mg} \cdot \mathrm{L}^{-1}\right.$ at neutral $\left.\mathrm{pH}\right)$, its decomposition by ultraviolet light is slow, providing years of protection even against direct sunlight. Selenium is used as a pigment (coloring agents) for paints, plastics, ceramics, and glazes [17]. Depending on the form of selenium used the color ranges from deep red to light orange. It can be used to decolorize glass and to impart a scarlet red color to glass, glazes, and enamels.

Arsenic (As) concentrations ranged from 2.9 to $2486.5 \mathrm{mg} \cdot \mathrm{L}^{-1}$ with an average of $180.03 \mathrm{mg} \cdot \mathrm{L}^{-1} .42 \%$ of the samples contained high arsenic concentrations above the maximum allowable value $\left(>25 \mathrm{mg} \cdot \mathrm{L}^{-1}\right)$ and about $13 \%$ of the samples had arsenic concentration $>300 \mathrm{mg} \cdot \mathrm{L}^{-1}$ (Table 1, Figure 2). It was quite clear that the amount of arsenic in children toy samples was very high compared to what is universally allowed, and there is no convincing justification for the presence of such large amounts in toys. Some pigments that may contain arsenic or some of its compounds, such as Paris Green (copper acetoarsenite), are used as a pigment, despite its toxicity, and as a blue colorant for fireworks [18]. The color of Paris Green is said to range from a pale, but vivid, blue green when very finely ground, to a deeper true green when coarsely ground. In contrast, arsenic was detected in only $29 \%$ of toy samples from Israeli market with average concentration of $16.68 \mathrm{mg} \cdot \mathrm{L}^{-1}$ (Table 2).

In the Palestinian Territories examination does not include all sectors. For example there is 24 important sectors not covered due to potential shortage, lack of specialized laboratories and sometimes to their need for inspector specialists, or because there is no Palestinian specification. These sectors include: toys, house wares, 
Table 2. Concentration of eight heavy metals $\left(\mathrm{mg} \cdot \mathrm{L}^{-1}\right)$ in toys from Israeli markets. Results expressed as (minimum, maximum, average, standard deviation (SD), and relative standard deviation (RSD)), as well as their ISO 8124-3 limits and total samples exceeding limits.

\begin{tabular}{cccccccccc}
\hline Heavy Metal & $\mathrm{Pb}$ & $\mathrm{Cd}$ & $\mathrm{Cr}$ & $\mathrm{Hg}$ & $\mathrm{As}$ & $\mathrm{Se}$ & $\mathrm{Ba}$ & $\mathrm{Zn}$ \\
\hline Minimum & 2.8 & 4.5 & 7.2 & $\mathrm{ND}$ & $\mathrm{ND}$ & 0.7 & 14.0 & 16.0 \\
Maximum & 96.7 & 75.9 & 59.0 & 25.0 & 22.4 & 342.0 & 489.0 & 500.0 \\
Average & 39.2 & 36.9 & 36.9 & 12.3 & 16.7 & 93.9 & 156.9 & 159.6 \\
SD & 1.1 & 2.2 & 1.8 & 1.7 & 1.2 & 4.9 & 3.5 & 3.8 & 2.9 \\
RSD (\%) & 2.7 & 6.0 & 4.9 & 13.7 & 6.8 & 5.2 & 2.2 & 2.4 \\
\% & 90 & 75 & 60 & 60 & 25 & 500 & 1000 & - \\
\% of total samples exceeding limits & 5 & 5 & 0 & 0 & 0 & 0 & 0 & 0 \\
\hline
\end{tabular}

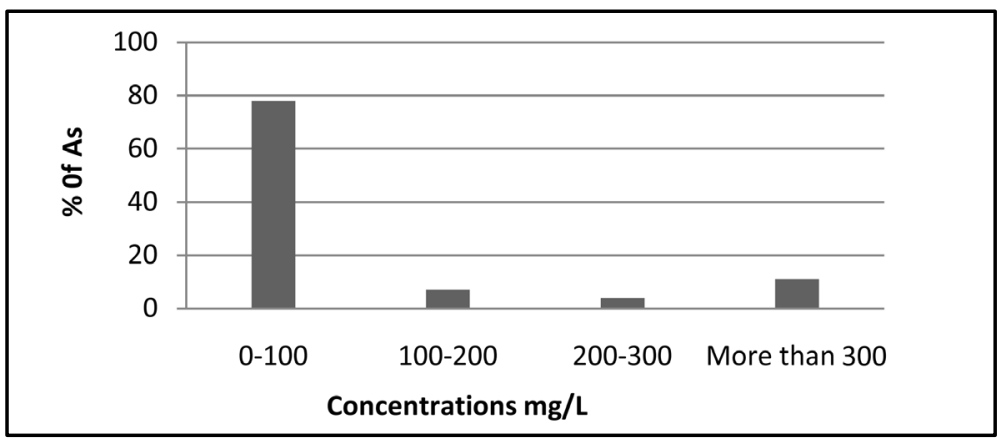

Figure 2. Percentage of as in Palestinian toy samples.

electrical and electronic appliances, automobiles and spare parts, and construction materials. Thus, the absence of the executive power, follow-up field, control and supervision, make a lot of goods, such as toys, enter the Palestinian cities from all directions [4].

\subsection{Heavy Metal Concentrations in Toys Purchased from the Israeli Market}

In contrast $94 \%$ of toy samples from Israeli markets are safe, only one sample out of seventeen contained $\mathrm{Pb}$ and $\mathrm{Cd}$ slightly higher than maximum allowable limit. The lead and cadmium total contents in one sample, which is a deep yellow JCP Tractor toy, were 96.7 and $75.9 \mathrm{mg} \cdot \mathrm{L}^{-1}$ respectively, and both values slightly exceeded the maximum allowable international limit, which is 90 and $75 \mathrm{mg} \cdot \mathrm{L}^{-1}$ respectively (Table 2). Concentrations of heavy metals in the toys ranged from 2.8 to $96.7 \mathrm{mg} \cdot \mathrm{L}^{-1}$ for $\mathrm{Pb}$ with an average value equal to $39.2 \mathrm{mg} \cdot \mathrm{L}^{-1}$, from 4.5 to $75.9 \mathrm{mg} \cdot \mathrm{L}^{-1}$ with an average value equal to $36.9 \mathrm{mg} \cdot \mathrm{L}^{-1}$ for $\mathrm{Cd}$, from 7.15 to $59 \mathrm{mg} \cdot \mathrm{L}^{-1}$ with an average value equal to $36.87 \mathrm{mgL}^{-1}$ for $\mathrm{Cr}$, ND to $25 \mathrm{mg} \cdot \mathrm{L}^{-1}$ with an average value equal to12.32 $\mathrm{mg} \cdot \mathrm{L}^{-1}$ for $\mathrm{Hg}$, $\mathrm{ND}$ to $22.4 \mathrm{mg} \cdot \mathrm{L}^{-1}$ with an average value equal to $16.68 \mathrm{mg} \cdot \mathrm{L}^{-1}$ for As, from 0.71 to $342 \mathrm{mg} \cdot \mathrm{L}^{-1}$ with an average value equal to $93.9 \mathrm{mg} \cdot \mathrm{L}^{-1}$ for Se, from 14 to $489.0 \mathrm{mgL} \mathrm{L}^{-1}$ with an average value equal to $156.29 \mathrm{mg} \cdot \mathrm{L}^{-1}$ for $\mathrm{Ba}$, and finally from 16.0 to $500 \mathrm{mg} \cdot \mathrm{L}^{-1}$ with an average value equal to $159.56 \mathrm{mg} \cdot \mathrm{L}^{-1}$ for $\mathrm{Zn}$ (Table 2, Figure 3).

\subsection{Migration Rates Experiment}

Migration rate is the amount of heavy metal which is released from the toy or article when it is submerged in artificial saliva solution. None of the values in the Table 3 had exceeded the international maximum allowable limit, which is the boundary between safety and danger. According to UN standards and EU standards Maximum Soluble Migrated Element in Toy Material are $60 \mathrm{mg} \cdot \mathrm{L}^{-1}$ for $\mathrm{Pb}, 75 \mathrm{mg} \cdot \mathrm{L}^{-1}$ for $\mathrm{Cd}, 60 \mathrm{mg} \cdot \mathrm{L}^{-1}$ for $\mathrm{Cr}, 25$ $\mathrm{mg} \cdot \mathrm{L}^{-1}$ for As, $60 \mathrm{mg} \cdot \mathrm{L}^{-1}$ for $\mathrm{Hg}, 500 \mathrm{mg} \cdot \mathrm{L}^{-1}$ for Se, and $60 \mathrm{mg} \cdot \mathrm{L}^{-1}$ for Sb (ISO, 2010). Concerning zinc standards, according to EN 71-3: 1994, the maximum migration allowable limit of zinc in a toy (mg/kg toy material) can be calculated from the following relation; [Element in toy $(\mathrm{mg} / \mathrm{kg}$ toy material) $\times$ weight of toy material 
Table 3. The migration rate $\left(\mathrm{mg} \cdot \mathrm{L}^{-1}\right)$ of eight heavy metals from 10 toy samples in artificial saliva. Results expressed as average \pm SD for three samples. (SD: standard deviation).

\begin{tabular}{ccccccccc}
\hline Toy type & $\mathrm{Pb}$ & $\mathrm{Cd}$ & $\mathrm{Cr}$ & $\mathrm{Hg}$ & $\mathrm{As}$ & $\mathrm{Se}$ & $\mathrm{Ba}$ & $\mathrm{Zn}$ \\
\hline Bracelet & $9.70 \pm 0.29$ & $11.20 \pm 0.85$ & $14.9 \pm 1.08$ & $0.52 \pm 0.84$ & $3.4 \pm 0.55$ & $23.80 \pm 1.67$ & $51 \pm 3.87$ & $41.2 \pm 2.05$ \\
Dinosaur & $18.50 \pm 0.95$ & $24.00 \pm 0.14$ & $19.2 \pm 1.19$ & $0.60 \pm 0.88$ & $9.2 \pm 1.03$ & $59 \pm 2.30$ & $53.20 \pm 3.16$ & $22.4 \pm 2.73$ \\
Lorry car & $32.10 \pm 0.99$ & $30.20 \pm 0.62$ & $24.1 \pm 1.65$ & $\mathrm{ND}$ & $12.80 \pm 1.69$ & $102 \pm 2.98$ & $66.70 \pm 3.81$ & $41.5 \pm 2.98$ \\
Banana & $11.20 \pm 0.15$ & $14.20 \pm 0.18$ & $10.5 \pm 0.47$ & $\mathrm{ND}$ & $15.30 \pm 1.87$ & $49.90 \pm 1.01$ & $67.90 \pm 3.38$ & $66.8 \pm 2.45$ \\
Truck car & $9.40 \pm 1.73$ & $11.30 \pm 1.06$ & $8.9 \pm 0.84$ & $\mathrm{ND}$ & $13.70 \pm 1.71$ & $55.40 \pm 1.78$ & $89.30 \pm 3.40$ & $112 \pm 3.02$ \\
Apple & $27.30 \pm 0.99$ & $25.10 \pm 1.58$ & $20.5 \pm 0.77$ & $\mathrm{ND}$ & $9.30 \pm 0.80$ & $86.10 \pm 1.95$ & $41.20 \pm 2.03$ & $15.0 \pm 0.94$ \\
Mobile & $35.80 \pm 0.71$ & $31.40 \pm 0.05$ & $28.8 \pm 0.53$ & $\mathrm{ND}$ & $7.36 \pm 1.69$ & $63.00 \pm 1.64$ & $56.40 \pm 3.81$ & $33.8 \pm 1.81$ \\
Football & $45.20 \pm 1.02$ & $40.20 \pm 1.46$ & $33.7 \pm 0.74$ & $\mathrm{ND}$ & $11.50 \pm 1.72$ & $48.00 \pm 1.66$ & $100.9 \pm 3.50$ & $62.3 \pm 2.55$ \\
Telephone & $19.50 \pm 0.39$ & $21.50 \pm 0.63$ & $19.2 \pm 1.63$ & $6.10 \pm 1.64$ & $14.50 \pm 1.76$ & $19.70 \pm 0.66$ & $78.30 \pm 3.62$ & $92.1 \pm 2.42$ \\
Caterpillar & $17.6 \pm 1.36$ & $22.60 \pm 0.50$ & $21.1 \pm 1.42$ & $2.90 \pm 1.23$ & $8.90 \pm 0.76$ & $45.90 \pm 1.14$ & $55.40 \pm 3.58$ & $100 \pm 3.53$ \\
\hline
\end{tabular}

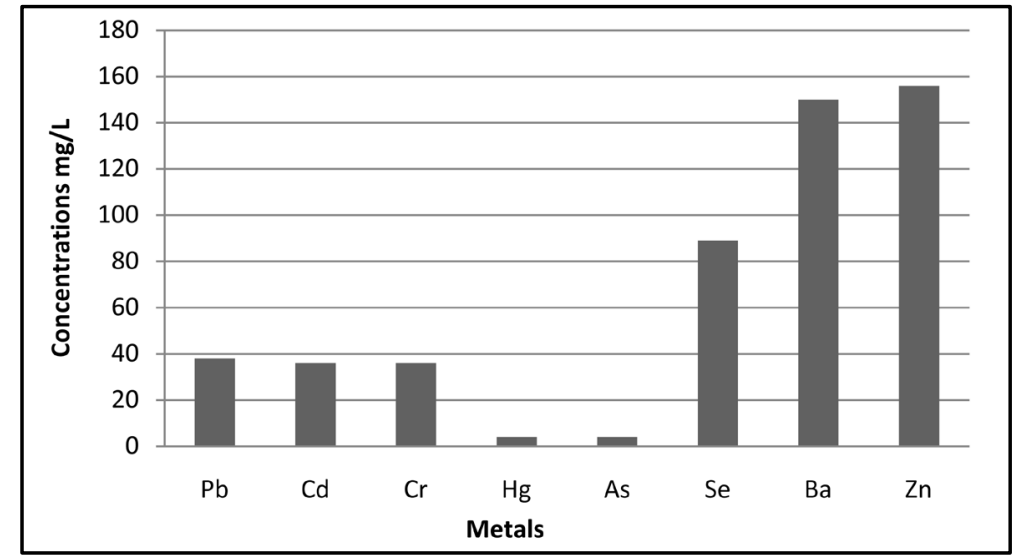

Figure 3. The average of heavy metals total content in Israeli toys samples.

(kg)/Body weight of child (kg)] must be $<10 \%$ of TDL, where TDL = Tolerable Daily Intake, and it is for Zn $350(\mu \mathrm{g} / \mathrm{Kg}$ bw/day). Accordingly, the limit of element in toy $(\mathrm{mg} / \mathrm{kg}$ toy material) $=10 \%$ TDI $\times$ Body weight child (kg)/weight of toy material present in toy $(\mathrm{kg})$ [19]. However, migration limit set by the EU Directives in scraped-off material should not exceed $46,000 \mathrm{mg} \cdot \mathrm{L}^{-1}$ [14] [20].

We must take into account that the child does not use the toy only once, but many times with varying periods. The child also plays with more than one toy at the same time. There are always possibilities for a cumulative effect. All of these toxins may accumulate in the body of the child and with time may exceed the maximum allowed. At this point the child is in real danger. We must differentiate between two important concepts in this area. The first one is total heavy metal content and the second is maximum soluble migrated element of toy material. In this case the material is placed under conditions which simulate contact with stomach acid for a period of time after swallowing. This method was adopted in the current study.

\section{Conclusion}

This study revealed that plastic toys sold in the Palestinian markets contained concentrations of heavy metals higher than the internationally maximum allowable. Forty-two percent of the toy samples showed high concentration (above international limits) of $\mathrm{Pb}, 30 \%$ of $\mathrm{Cd}, 34 \%$ of $\mathrm{Cr}, 6 \%$ of $\mathrm{Hg}, 42 \%$ of As, 32\% of Se, $20 \%$ of $\mathrm{Ba}$ and $40 \%$ of Zn. On the other hand, $94 \%$ of toy samples from Israeli markets are safe (one sample out of seven- 
teen contained lead and cadmium slightly higher than maximum allowable limit). None of the migration rates of the eight heavy metals from toy samples submerged in artificial saliva had exceeded the international maximum allowable limit, which is the boundary between safety and danger. Acting quickly by adopting policies to protect and educate consumers about the risks posed by plastic made toys needs a special attention which could help protect children's lives especially in Palestine. Also, it will decrease heavy metals pollutants that are released from the plastic to the Environment at the end of the Plastic lifecycle.

\section{References}

[1] Lester, S. and Belliveau, M. (2004) PVC: Bad News Comes in Threes. The Poison Plastic, Health Hazards and the Looming Waste Crisis. Center for Health, Environment and Justice, Falls Church.

[2] Allen, L.P., Comolli, R. and Heumann, S. (2008) China Product Recalls: What's at Stake and What’s Next. National Economic Research Associates, Inc., NERA Economic Consulting, New York, 1-16.

[3] Consumer Federation of America (2008) Total Recall: The Need for CPSC Reform Now. CFA, Washington DC.

[4] Abul Khair, M.A. (2007) Palestinian Crossings Legal Political Vision. Arab Commission for Human Rights, London.

[5] Kingston, H.M. and Haswell, S.J. (1997) Microwave-Enhanced Chemistry: Fundamentals, Sample Preparation, and Applications. American Chemical Society, Washington DC.

[6] ISO 8124-3 (2010) Safety of Toys, Part 3: Migration of certain elements. ISO TC181.

[7] Van Alphen, M. (1999) Lead in Paints in Water in India. Proceedings of the International Conference on Lead Poisoning Prevention \& Treatment: Implementing a National Program in Developing Countries, Bangalore, 8-10 February 1999, 265-272.

[8] Brigden, K., Santillo, D. and Johnson, P. (2008) Playing Dirty Analysis of Hazardous Chemicals and Materials in Games Console Components. Greenpeace International, Amsterdam.

[9] Greenpeace (2008) Poisoning the poor Electronic Waste in Ghana. Greenpeace Report August, Amsterdam.

[10] Blaurock-Bush, E., Amin, O.R., Dessoki, H.H. and Rabah, T. (2012) Toxic Metals and Essential Elements in Hair and Severity of Symptoms among Children with Autism. Maedica: A Journal of Clinical Medicine, 7, 38-48.

[11] Geier, O.A., Kern, J.K., King, P.G., Sykes, L.K. and Geier, M.R. (2012) Hair Toxic Metal Concentrations and Autism Spectrum Disorder Severity in Young Children. International Journal of Environmental Research and Public Health, 9, 4486-4497. http://dx.doi.org/10.3390/ijerph9124486

[12] United Nations Environmental Program (UNEP) (2008) Expanding the Number and Scope of Partnership Areas within the United Nations Environment Program Global Mercury Partnership. http://www.chem.unep.ch/MERCURY/UGMP/K0820334_\%20Partnership\%20-\%201-3.doc

[13] Folarin, O.M. and Sadiku, E.R. (2011) Thermal Stabilizers for Poly(vinyl Chloride): A Review. International Journal of Physical Sciences, 63, 4323-4330.

[14] European Council (2009) Directive (2009)/48/EC of the European Parliament and of the Council.

[15] Erdodu, C.A. (2004) The Development of Synergistic Heat Stabilizers for PVC from Zinc Borate-Zinc Phosphate. Izmir Institute of Technology, Izmir.

[16] Sherman, L. (2011) Antimicrobial Additives Targeted to Healthcare. SpecialChem, Dec 21.

[17] Los Alamos National Laboratory, Crescent Chemical Company (2001) Lange’s Handbook of Chemistry. 15th Editions, University of Tennessee, Knoxville.

[18] Agency for Toxic Substances and Disease Registry (ASTDR) (2007) Toxicological Profile for Arsenic. US Department of Health and Human Services, Public Health Services, Atlanta.

[19] National Institute for Public Health and the Environment (RIVM) (2006) Chemicals in Toys RIVM/SIR Revised Advisory Report 0010278A02. RIVM, The Netherlands.

[20] EN (British Standards) (2006) Safety of Toys_-Part 3: Migration of Certain Elements. BSEN71-3. European Committee of Standardization, Brussels. 
Scientific Research Publishing (SCIRP) is one of the largest Open Access journal publishers. It is currently publishing more than 200 open access, online, peer-reviewed journals covering a wide range of academic disciplines. SCIRP serves the worldwide academic communities and contributes to the progress and application of science with its publication.

Other selected journals from SCIRP are listed as below. Submit your manuscript to us via either submit@scirp.org or Online Submission Portal.
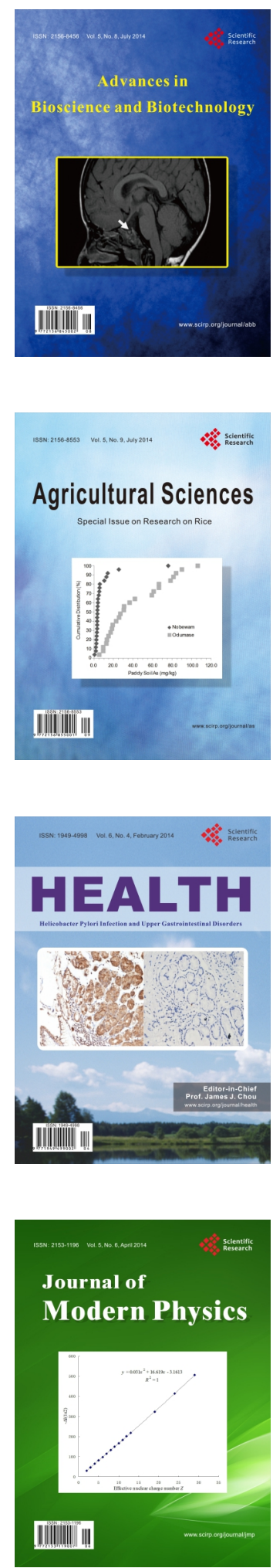
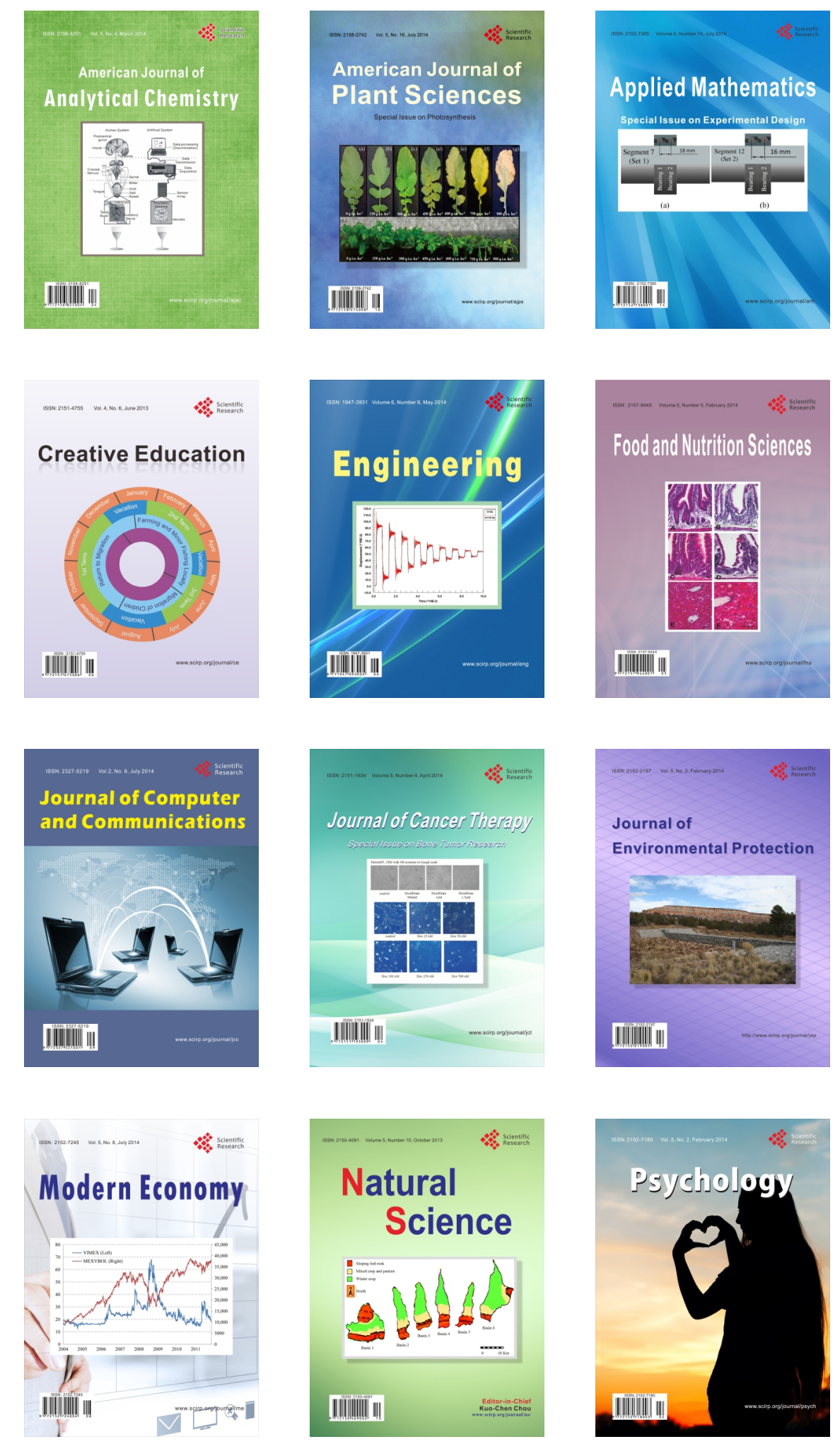